Unity Journal

Vol. III, 165-182, 2022

Doi: https://doi.org/10.3126/unityj.v3i01.43323

Prithvi Narayan Shah Research Center

Directorate General of Military Training, Nepali Army

Kathmandu, Nepal

\title{
Rediscovering the Contemporary Relevance of National Security Strategies in Divya Upadesh: A History-Policy Relationship
}

\author{
Gaurav Bhattarai
}

\begin{abstract}
Rediscovering the past to build a secure future is better realized by understanding the role of history in policy making. Today, while Nepal's national security policies remain silent about the geopolitical threats, it is timely to rediscover the guidelines on national security strategies introduced in Divya Upadesh, a Divine Counsel of the Great King Prithivi Narayan Shah. Currently, Nepal inability in escaping the geostrategic challenge of accommodating the interest of major powers is explicitly visible in the fiasco created by the Nepali political parties in the context of Nepal's uncertainty over US-sponsored Millennium Challenge Corporation (MCC) project, which is today perceived in Nepal as hostile to China-led Belt and Road Initiative (BRI). Historically, Nepal has successfully balanced its two Gulliverian neighbors. But, today, Nepal is not in a position to evade the repercussions triggered by Sino-Indian rivalry at the regional front and Sino-US strategic competition at the global level. On the backdrop of their conflicting intereststrategic, security, economic-Kathmandu faces the geostrategic challenges of accommodating the interest of major powers. Although Nepal's integrated foreign policy of 2020 mentions of the changed geopolitical
\end{abstract}

context, pragmatic policy recommendations, as indicated by foreign policy behavior, are missing. Constitutional guidelines on Nepal's foreign policy and national security alone are not sufficient. Thus, drawing lessons from history could be of help to formulate the national security strategies in order to better cope with the external threats. The rationale behind considering Divya Upadesh is to make Nepali policy makers realize that the national security strategies and policies that Nepal adopted in a usual/normal context won't be able to fulfill the requirements of the uncertain strategic milieu against the backdrop of a 'new Cold War' brewing between the United States and China. In the late $18^{\text {th }}$ century when P.N Shah was introducing a comprehensive national security policy for the first time, the external environment wasn't much favorable. After his death, however, instead of paying heed to his guidelines, expansionism ended up to territorial loss, adventurism led to Himalayan wars, appeasement led to increasing British influence in Nepal. After 1950, guidelines in Divya Upadesh have been more confined to history books and classrooms lectures. While Nepal lionizes its act of balancing India and China though the policy of non-alignment and equidistance, foreign and security policy makers never paid attention to reinvent the lesson for the 
same. Thus, this qualitative study recuperates the relevance of effective balancing as advocated by PN Shah in addressing the challenges surfaced while accommodating the interests of major powers. Most of the available literature on Divya Upadesh are either translated English versions, or limited to the analysis of the unification process. The relevance of an intersection of foreign policy and national security in Divya Upadesh is not unveiled by any of the available literature. Apprehending the same research gap, this study explores the contemporary significance of Divya Upadesh while devising the national security policies and strategies. Firstly, the contemporary challenges to Nepal's national security prompted by Kathmandu's struggle in accommodation of the interest of major powers is discussed; secondly, the policy of 'balancing' counseled by Prithivi Narayan Shah is emphasized as an apt and relevant in dealing with the contemporary challenges emanating from the neighborhood and beyond. Thirdly, "meticulous diplomacy," is highlighted to offer economic shape to the act of balancing. Finally, it has been realized how studying history means studying causes, and as such, turning the pages of Divya Upadesh, policy makers discover the causes of Nepal's failure in accommodating the interest of major powers.

Keywords: Divya Upadesh, National Security Strategies, Geo-strategic Location, Foreign Policy Objectives

\section{Introduction}

The great German thinker Karl Marx once said, "History repeats itself, first as a tragedy, second as a farce". In Nepali context too, events associated with national security have a pattern of repeating, and mostly they repeat in forms of geopolitical challenges. From the days of unification to the rise of China, what hasn't substantially changed is the geographical location. As such, the threats stemming from geopolitical vulnerabilities have always sustained: as a buffer during the age of colonialism; as a small state with the integration of Tibet into China; and as a weak state because of protracted political instability. Despite such analogies, which can be easily derived through a historical knowledge, geopolitical threats don't find a place in Nepal's national security policy and foreign policy objectives and priorities. The Fifteenth Plan(Fiscal Year 2019/20-2023/24) of the Government of Nepal has envisioned the provision for peace and security with the help of national security policy in three ways: Firstly, by assuring the holistic human security; Secondly, by making all the security agencies--Nepal Army, Nepal Police, Armed Police Force Nepal, and National Investigation Department-- professional, strong, inclusive and accountable to the citizens; Thirdly, by making the citizens ready and capable of serving the nation as per the national requirements" (National Planning Commission, 2020). On the external security, the Fifteenth Plan has called for the implementation of defense policy by strengthening the external security system. Failure to develop national security system in a timely manner, failure in managing border security and institutional deficiencies is often identified as the major bottleneck to Nepal's national security (National Planning Commission, 2020). Despite the realization to strengthen the national security apparatus, no serious attempts have been made towards timely reforms in the policy and strategy. Risks and threats stemming from geopolitical vulnerabilities are nowhere discussed in the national security strategies and policies. While Nepal's geographical location has 
once again gained strategic significance in the context of the rise of China, none of our policies - foreign and security - offer a clearcut guidelines to minimize the geopolitical risk emanating from the Sino-US strategic competition and Sino-India rivalry. As we remain deprived of the policies to reduce the geopolitical threats springing from the great power competitions, what could guide Nepal better than the Divya Upadesh, the foundation stone of Nepal's national security policy. Because, Divya Upadesh not only highlights the geopolitical threats and challenges but also recommends the ways to minimize them, particularly in the uncertain and perilous strategic environment. Hence, this study argues that it is appropriate to turn the pages of Divya Upadesh, while Nepal stands at the geopolitical crossroads, today, struggling to accommodate the interest of major powers.

Geopolitically speaking Nepal's own freedom and security depend on the amiable relations between her two big neighbors, India and China. Nepal's act of 'balancing' as suggested in Divya Upadesh is an upshot of the similar realization regarding how meticulously Nepal must tread the diplomatic tightrope, when relations between the two Asian giants, whose friendship and cooperation Kathmandu cherishes in all occasions, display signs of strain (Shaha, 1965, p. 86). Although Divya Upadesh was introduced when British colonialism was spreading in South Asia, the message it delivers is still relevant. Throughout the period of British colonialism in South Asia, Nepal was identified as a buffer state. The buffer state developed as a distinct political terminology in 1883(Ross, 1986, p. 16) and British were first to use the concept in Afghanistan in separating Russian and British sphere of influence during the Great Game (Fazal, 2004, pp. 311-344). Britain employed the concept of buffer in Nepal and Tibet as well. Two conditions are fundamentally inescapable to be a buffer state. First, buffer state is situated between the two archrival countries and it is relatively smaller in size and influence than rival countries flanking it. However, the function of buffer state is to maintain peace between the powerful countries. Today, while such colonial construct still persists in perceiving Nepal as a buffer state between India and China, Kathmandu needs to meticulously assess whether New Delhi and Beijing are truly its archrivals. China and India fought a war in 1962, but it was limited to few border areas. Sino -India relationship, today, is triggered by three Cs: Cooperation, Competition and Conflict. Wuhan meets between Prime Minister Modi and President Xi, Modi's address in Shangri-La dialogue, and their vitalizing presence in bygone Shanghai Cooperation Organization (SCO) conference exemplify the spirit of cooperation. While the border standoffs, skirmishes and conflict over Himalayan borders between them indicate at a conflict, it also cannot be denied that they have been competing in different international organizations and multilateral forums. Thus, in formulating national security policies, geopolitical accounts also need to be taken into consideration, and this is what Divya Upadesh teaches us. But, assessing the policies and programs of the government of Nepal, it has been understood that geopolitical details are often overlooked. For instance, in the policies and programs for fiscal year 2020-21, Nepal government expresses its commitment to fulfill the goal of 'prosperous Nepal and Happy Nepali' by building a 'healthy, educated and just' society that ensures economic, social and cultural security. But, nowhere in the policies and programs, the threats emanating from the 
geopolitical vulnerabilities are discussed. As Nepal is located in critical geography, it's not possible to disassociate Nepal's economic development, prosperity and overall public happiness from its geographical location. Being surrounded by the nuclear powers and archrivals, Nepal's security threats have always burgeoned. In such a context, when rival powers are attracted towards Nepal, our policymakers should be aware about the certain ways to minimize the geopolitical threats stemming from the interests of the major power countries, or specific policies targeted to boost up Nepal's preparedness in dealing with the repercussion of the 'New Cold War'. The high-risk external environment has obliged us reevaluate the productivity of Nepal's attempt to neutrality and non-alignment in dealing with the geopolitical rivalry between the great and major powers.

As Divya Upadesh eloquently manifests the co-relation between national security apparatus and foreign policy, small countries like Nepal may be largely benefitted by the counselling of Prithivi Narayan Shah on the act of balancing, national unity, effective institutionalization of foreign affairs, tactful diplomacy and promotion of economic diplomacy. Particularly, it directs the policy makers, foreign policy analysts and security experts the ways to minimize geopolitical risks that a small country located between the two rival countries faces. As India and China engage in a bitter geopolitical rivalry, small states like Nepal in their vicinity are obliged to pay close heed to their strategic and economic concerns. At present, China is apparently lobbying with the small states in South Asia to expand its markets and investment opportunities. But India is resisting. India claims South Asia comes under its sphere of influence, and is hence putting pressure on small states not be lured by China's bait. Whenever the two powers feel their concerns are not heeded, small states have been penalized. When Nepal dared to discount India's diktat over the new constitution, it was harshly punished with a cruel blockade. When Ulaanbaatar hosted Dalai Lama, Beijing imposed a brief economic blockade on Mongolia, another comparably small state. Clearly, the geopolitical rivalry between India and China affects the maneuverings of smaller states in their neighborhood. The small states, however, always aspire to benefit from the rapid economic development of the two Asian giants. Economic developments of India and China have given hope of "spillover effects' to Nepal as well. But it is not just its sensitive geostrategic location Nepal has to contend with. Its protracted political transition further complicates Nepal's neighborhood policy. Thus, rediscovering the contemporary relevance of national security strategies discussed in Divya Upadesh could offer a sigh of relief.

\section{Review of Literature}

National Security is variously understood and defined. For Walter Lippmann, "a nation is considered as secure, when it doesn't have to sacrifice its legitimate interests to avoid war, and is able, if confronted, to maintain them by war" (1943, p. 51). Protection of sovereignty, territorial integrity and political independence are the legitimate interest. Divya Upadesh has stressed on the importance of skillful balancing to minimize the geopolitical threats and maintain the national security of Nepal. For Arnold Wolfers, "security rises and falls with the ability of the nation to deter an attack or to defeat it" (1962, p. 150). Divya Upadesh has offered guidelines on augmenting nation's capabilities to deter the internal 
and external security threats. Barry Buzan has perceived security as a liberation from any kinds of dangers and threats. Without security there cannot be development and without development there cannot be security (Buzan, 1991). Therefore, there is a need for a coherent and mutually supportive security and development policies, if a country wants to achieve effective and sustainable development. With this, the concept of security has acquired a broader meaning that encompasses political, economic, social and cultural security.

The conventional underpinnings on national security discourses highlight on ensuring the physical security of the nation and protecting the population (Watson, 2008, p. 32) but with the introduction of the concept of human security, individuals have been kept at the center of analysis in the security studies. Human security in its broadest sense highlights 'the legitimate concerns of ordinary people who seeks security in their lives (United Nations Development Program, 1994). In today's world, it encompasses human rights, good governance, access to education and health care, and ensuring that each individual has opportunities and choices to fulfill his or her own potential. Every effort in this direction is also a step towards reducing poverty, achieving economic growth and preventing conflict.

Most of the available literature on Nepal's national security deal with the issues of security challenges (Bhattarai \&Wagle, 2010) internal and external threats, changing security dynamics (Bhattarai \& Cave, 2009), agenda of security sector reforms (Budhathoki, 2009), role of National Security Council (Wagle, 2009), rehabilitation and integration of Maoist combatants (Bhatt, 2010 \& Gautam, 2009) democratic control of security forces (Kumar, 2009). There are abundant of literature dealing with the role of security providers-- Nepali Army, Nepal Police Armed Police Force, National Intelligence Department and private security companies, and roles of security related actors-- judicial system, criminal justice system, National Human Rights Commission, civil society and media (Sapkota, 2009). Although the issue of human security has been explored, it is also limited to the concepts, issues and challenges (Upreti, Bhattarai \& Wagle, 2013). There is a dearth of literature arguing how history provide a refuge in resolving the contemporary problems, Divya Upadesh being one of them, when it comes to geopolitical challenges faced by Nepal's national security. But Diva Upadesh is still "too little known and too little appreciated" (Stiller, 1968: iii). Here, both, Nepal's foreign policy and national security strategies share the blame. While Nepal's foreign policy concentrated itself more on the routine activities instead of forging effective ways and building appropriate foreign policy institutions to minimize the geopolitical risks through foreign policy priorities, objectives and behaviors, Nepal's national strategies have restricted geopolitical threats only to the territorial threats. While Divya Upadesh recommends the diplomatic efforts to reduce the geopolitical vulnerabilities by positioning the interconnection between foreign and national security, the objective of this study is to rediscover the contemporary relevance of national security strategies in P.N. Shah's Divya Upadesh.

The constitutional provision for Nepal's National Security is: "There shall be a National Security Council for making recommendation to the Government of Nepal, Council of Ministers for the formulation of a policy on overall national interest, security and defense 
of Nepal, and for the mobilization and control of the Nepal Army"(Constitution of Nepal, 2015) In the 2015 Constitution of Nepal, Article 5, Article 51, Article 266, Article 48, Article 50, Article 267 have included several provisions related to national security( ibid). As public policies in a democratic state are directed by the spirit of constitutionalism, national security policy is formulated as per the constitutional instructions. In the March of 2019, K.P-Oli-led government passed the national security policy. It is the revised and updated version of 2016 national security policy, which was drafted in a changed political context (Pokharel, 2020). But, has it addressed the geopolitical threats that Nepal has faced in the wake of the development of new strategic partnerships and alliances to contain the rise of China? Has the revised national security policy addressed the challenges faced by Nepal's traditional survival strategies, including neutrality and non-alignment? Does the updated national security policy help Nepal to cope effectively against the changing security dynamics globally and regionally? Has the new national security offered ways for Nepal to deal with the Sino-Indian rivalry and Sino-US strategic competition?

Prithivi Narayan Shah delivered Divya Upadesh amidst the presence of disciples, priests, nobles, tutors and household including Thar Ghar, Pandey, Arjyal, Pantha, Rana, Khanal and Bohora when he shifted his capital from Nuwakot during the last days of his life (Gautam, 2074 B.S, p. 70). His instructions not only deal with the unification campaign, but also offer ways to minimize the geopolitical threats and direct the power elites to good governance, sound diplomacy and nationalism, in order to guarantee the security and survival of Nepal from the external threats. Thus, it is appropriate for the policy makers and strategists to dig into Divya Upadesh in order to rediscover its contemporary relevance. Although its date of publication is not clear, it was edited by Yogi Naraharinath in 1959 in Nepali Devanagari script and its English translation was done by Ludwing Stiller in 1968.

\section{Method}

This qualitative study examines the contemporary relevance of Divya Upadesh on Nepal's national security strategies with the help of data and information available from both the primary and secondary sources. P.N Shah's counselling on national security and foreign policy apparatus has been studied. Various treaties and agreements have been surveyed. Media sources were also reviewed to understand the contemporary challenges faced by Nepal in accommodating the interest of major powers. Challenges are listed, discussed and critically analyzed while the literature on foreign policy of 'balancing' is adequately reviewed. The themes that emerged from the reviews are thematically analyzed and interpreted. The thematic analysis has been done by closely examining the qualitative data to identify the geopolitical challenges faced by Nepal in accommodating the conflicting interests of the major powers. Once qualitative data are familiarized, they are organized through coding and interconnected themes are highlighted that reinforce the major argument on how it is best to rediscover the contemporary relevance of national security strategies in Divya Upadesh. Here, the concept of rediscovering has more to do with what E. H Carr has stated in What is History? (1961). According to Carr, "the study of history is the study of causes". Thus, analyzing the strategic guidelines offered by the Divya Upadesh, which was introduced 
when Nepal was exposed to the uncertain and risk-bound external environment, today's foreign policy makers and national security strategists could understand the prime geopolitical causes confronted by Nepal today and their impacts on Nepal's national security. One may argue how the policy guidelines offered during the ear of expansionism could be of help in the today's democracy. Here, it's best to remember that among all the foreign policy variables, geography remains the constant. From the days of its foundation to today's time, Nepal has always faced India and China as its neighbors. Still, the nature of geopolitical risks has varied with the change of time. But it doesn't mean the importance of Divya Upadesh can be undermined as a mere accumulation of objective facts. Rather, this study calls for consulting the historical productions like Divya Upadesh to shape today's policies. Thus, with the idea of rediscovering national security guidelines in Divya Upadesh, this study intends to highlight how history should be understood as a means to resolving present problems instead of confining it to the act of storytelling. Policy makers must rely on their understanding of the past while attempting to understand what is happening in the present. Thus, resorting to Divya Upadesh offers them perspective and analytical leverage on the major issues of geopolitical significance. One cannot craft policies solely on the basis of historical information or by surveying the intellectual history. But one also cannot ignore what history has to offer.

\section{Discussion and Analysis}

Accommodating the Interests of Major Powers: Although there is a limit of historypolicy relationship, the competing narratives offered by history cannot be ignored. As the objective of this study is to highlight the significance of revisiting Divya Upadesh, which is a historical production to draw inferences for foreign and security policy making in present context, policymakers need to be able to distinguish between the insights offered by history. Because, history itself cannot provide a clear or definitive answers to the complex policy choices in an uncertain environment. But history can definitely provide an assistance to mull over a given problem more meticulously and logically. In today's context, the major problem faced by Nepal's foreign and security policy is the lack of rigor and intelligence to resolve a problem. As Nepal faces the challenges of accommodating the interests of major powers, today, foreign policy and security experts are divided over kinds of survival strategies available to Nepal including hedging, neutrality, non-alignment, equidistance and so on. While the objective of all these policies is effective balancing, why should Nepali policy makers hesitate to revisit Divya Upadesh - a key source of balancing as a policy, posture and strategy.

China's rise in world affairs has definitely increased Nepal's strategic prominence. Concurrently, difficulties in handling the interests of major powers have also perceptively bourgeoned (Acharya, 2020, p.5) while new alliance systems are being devised to contain China, in the Asian Pacific region. Group of Seven (G7) countries have already developed a consensus to develop a Build Back Better World (B3W) plan in order to counter China-led Belt and Road Initiatives (BRI) (BBC, 2021) of which Nepal is also a member. The United States, India, Japan and Australia have devised the Quadrilateral Security Dialogue(theQuad) with anobjective to contain China, while India and the US has inked Basic Exchange and Cooperation 
Agreement on Geospatial Cooperation (BECA) to face off China's influence through geospatial intelligence (BBC, 2020). In such an unfavorable context, where Nepal's southern neighbor is aligned with the West in containing northern neighbor, how shall Kathmandu proceed in such an uncertain and complex strategic setting, while the global politics and regional security dynamics are in a state of flux, because of the changing power relations? (KC \& Bhattarai, 2021, pp. 157-174). Historically, Nepal has been effectively balancing its diplomatic posture between India and China (Kissinger, 2014). But, the ongoing geopolitical rivalry between India and China has added more challenge to Nepal's foreign policy of neutrality and non-alignment. Nepal's neutrality and nonalignment was severely condemned by New Delhi in the June of 2020 when the border skirmishes between the two nuclear powers almost obligated South Asian countries to take a side (Zheng, 2020). Although Nepal expressed a stern belief in nonalignment and neutrality (Ghimire, 2020), India instantly questioned it referring to China's increasing presence in Nepal (Gupta, 2020). But, Kathmandu perceived India's suspicion over Nepal's neutrality as the upshot of new map row between them (The Times of India, 2020). In 2019 Nepal expressed its reservation over India's new map for having incorporated Nepali territories unilaterally. Kathmandu also dispatched diplomatic note to New Delhi, seeking a diplomatic resolution. But, as New Delhi paid no heed to it and constructed a road to Mansarovar in Tibetan Autonomous Region via Nepali territories, Kathmandu also unveiled a new map incorporating the disputed territories with India. While New Delhi paid no attention to Nepal's repeated calls in resolving the border problems (Republica, 2020), it offered an opportunity for the then ruling communist party in Nepal to draw geopolitical benefits out of the Sino-Indian dispute. But, such geopolitical benefits are usually aimed at moderating Indian influence in Nepal, by crawling towards China. Even Nepal's recent efforts for trade diversification and railway projects with China, is perceived by India as the upshot of Nepal's increasing discomfort with India, which is not a new experience however. In 1960s, when Araniko highway was being constructed connecting Nepal's capital with Chinese borders, Chairman Mao had commented that "once these roads are opened, India may be a bit more respectable towards you".

While India-China war was underway in 1962, there were reports in the press questioning whether the war was to Nepal's benefit (Khanal, 2000). Even though Nepal was not involved, Nepal's neutrality drew a severe criticism in the Indian media, and SinoNepal relations were portrayed as anti-Indian and pro-Chinese (ibid). Kathmandu faced the same fate when India lost its 20 soldiers during a violent skirmish in Galwan valley in 2020 with China. Despite not being able to defend its neutrality, Kathmandu still reckons neutrality, non-alignment and equidistance as relevant owing to its geo-strategic location. In fact, they are the survival strategies of the small states in coping with the gigantic neighborhood. However, they have been undergoing through an alarming trials and tribulations actuated by the geopolitical impacts of the Sino-Indian conflicts. After all, Nepal's policy of balancing shouldn't be perceived as the geopolitical ambition in reaping benefits out of the Sino-Indian conflict, while the lack of a clear-cut neighborhood policies from Nepal has already generated distrust and misperceptions in the 
psyche of its immediate neighbors. On June 19, 2020, when the Nepal Communist party had a virtual meeting with the Communist Party of China, it was severely criticized by Indian media as being hostile to New Delhi, as the virtual meet coincided at the time when the bilateral relations between India and China had gone to low ebb because of the border scuffles leading to a violent clash along the disputed borders in the Himalayan region. As the virtual meeting took place at the time when Nepal-India border disputes reignited, it made New Delhi generate doubt over Nepal's neutrality as most of the Indian media instantly endorsed the Indian army chief's remarks: "Nepal is acting on the behest of someone" (The Wire, 2020).

Even though the meeting was scheduled long before the skirmishes ensued between Indian and Chinese troops, the timing was not appropriate. It could have been averted. But, failure in doing so, geopolitical ambition of the then ruling communist party drew widespread criticism. The criticism wasn't limited to New Delhi, however. Even Kathmandu-based foreign policy experts and security analysts condemned Nepal's perceptible geopolitical ambition over Sino-India disputes, reckoning such acts as disastrous for the landlocked country's aspiration in bridging two economic giants. India's spectacular economic performance and China's unrivalled development has always given a hope of spillover effects to Nepal, whose search for economic prosperity is dependent on its transit diplomacy (K.C. \& Bhattarai, 2018, pp.75-96). But, quite often, the geopolitical dispute between India and China prompts the spirit of geopolitical ambition in the leaderships of small states in South Asia, and as a result they take no less time to prioritize the interest of one nuclear-armed country against that of the other, mostly to protect their government back home, or at least to prolong their stay in power, eventually jeopardizing Nepal's neutrality (Rose, 1971, pp.177-207).

Hence, it becomes clear that Nepal's foreign policy of neutrality and non-alignment alone are not sufficient to manage its relations with India, China and the US under the pretext of increasing Sino-India and Sino-US rivalry. Being a member of China-led BRI, Kathmandu's dillydallying over U.S.-funded Millennium Challenge Corporation (MCC) grant of 500-million investment plan for roads and electricity transmission lines may impact Nepal-US relations. It also indicates at Nepal's fruitless attempts in managing the interests of the major powers. In Kathmandu, the general mass perceives BRI and MCC as hostile to each other (Vater, 2020), which is not the reality, however. Even the powerful leaders of the communist party deem MCC grant as the part of Indo-Pacific Strategy to contain the rise and influence of China's in the region (Adhikari, 2020). Such observations are the results of the great power politics in the Himalayas, which needs to be diplomatically managed, and in failing to do so, may severely impact Nepal's national security and foreign policy apparatus (KC \& Bhattarai, 2021, pp. 157-174). There are opinions in press claiming how US-China rivalry in Nepal has delayed MCC project (Jha, 2020). But, when the deal was signed in 2017 with the United States, there was no uproar and it was believed that MCC would be easily ratified by the parliament. But, as soon as it was linked with the Indo-Pacific Strategy, disputes and disagreements instantly surfaced, leaving MCC in limbo (KC \& Bhattarai, 2021, pp. 157-174). Although the US's future policy towards Kathmandu is determined by the 
fate of MCC in Nepal, Kathmandu cannot afford to be part of any strategic alliance led by great powers (Acharya, 2020). Even though the Trump administration branded Nepal as its strategic partner in Indo-Pacific Strategy, Nepal overtly repudiated it (The Rising Nepal, 2019). Equally, Washington as perceived BRI projects in Nepal, as serving the interest of China, instead of Nepal (The Kathmandu Post, 2019). The U.S. Department of Defense has emphasized on developing partnership and expanding defense relations with Nepal (DoD, 2019) as mentioned in its 2019 Indo Pacific Strategy Report, "Preparedness, Partnership and Promoting a Networked Region". Also, in its report "A Free and Open Indo-Pacific: Advancing A Shared Vision" the U.S. Department has highlighted on "enduring strength of the U.S.-Nepal partnership and the close peopleto-people ties that form the foundation of the relationship" (DoS, 2019). Apprehending the same, some influential communist leaders have opposed MCC perceiving it as part of IPS and ratifying it from the parliament would push Nepal into a military alliance (KC \& Bhattarai, 2021, pp. 157-174). Although the Kathmandu-based US Embassy has stressed that MCC has no military components and aims to support Nepal's energy sector and advance connectivity to bolster growth and private investment (MCC, 2017), foreign aid and investment in Nepal should be understood from its geostrategic role (Sharma \& Seddon, 2020). During the cold war, China, the United States, India competed to spend on the infrastructure and development projects in Nepal (Mihaly, 1965). With the fall of bipolarity and end of the cold war, particularly with the rise of China, New Delhi and Beijing have been competing in Kathmandu. Today, as China-led BRI projects in Nepal increase day-by-day, the interests of the US and its strategic partner India have converged on the issue of containing China, resulting into a great power game in the Himalayas (Stobdan, 2019) and generating convulsions for countries like Nepal in managing the interest of major powers.

In such an adverse environment triggered by great power competition, which has also impacted Nepal's policy choices, analogies could be a source of insight. Because analogies are the most important aspect of history-policy relationship. What analogies teach to the policy makers is that events happening in the present is like those events that happened in the past. Thus, efforts to draw policy options by identifying historical similarities and differences may be of help in dealing with the present-day crisis of similar nature. While the nature of great power game in Himalaya may have changed, but securitization of Himalayas by the powerful countries is not a fresh instance. Thus, turning the pages of Divya Upadesh, Nepali security and foreign policy makers may use comparative analogies by scrutinizing two or three or more episodes resembling the current episode. While Divya Upadesh demands effective balancing of Nepal's gigantic neighborhood, policy makers could assess Nepal's act of balancing through the policy of appeasement which Nepal exercised to cope with the British colonialism in South Asia; or they could also weigh Nepal's act of balancing by forging 'special relations' with India in the context of the integration of Tibet into China. Also, Nepali policy makers could evaluate Nepal's balancing from the policy of equidistance the Himalayan country has adopted to balance both the neighbors.

Actof Balancing: Essentially, its geo-strategic location has driven Nepal, located between two nuclear powers, to exercise the policy 
of neutrality and nonalignment historically. But Nepal's neutrality and nonalignment has been variously critiqued and appraised, particularly during those junctures, when Nepal finds itself in a difficult position to balance both of its immediate neighbors. As an act of balancing allows countries to adapt to their environments be inventing strategies capitalizing on geostrategic strength and compensate for the geostrategic challenges (Handel, 1995, p. 534), it is advantageous for small states like Nepal to accommodate the diverse and conflicting interest of major powers. The same realization was present in Divya Upadesh. Nepal's act of balancing is historically characterized with the metaphor of 'yam' assigned by Prithivi Narayan Shah, the founder of Modern Nepal, in his Dibhya Upadesh, a divine council on statecraft. For Shah:

Nepal is like ayam (gourd) between two stones. Keep strong friendship with the Emperor of China; one has to maintain friendship with the Emperor of the sea (English Emperor) in the south. But he is very clever. He is occupying Hindustan. He is eyeing the plane area (of Nepal also). When Hindustani (Indian) people will woke-up (not tolerate them) he may find difficulty to stay there (...) we have to find out our Sandhisarpan (weak points) and we also have to change them into the strong forts. We have to create obstacles on the way they try to enter into. Mind it they may arrive here anytime"

But his divine council couldn't guide Nepal's expansionist rulers, particularly after the time when Nepal lost war to British India in the Anglo-Gurkha war of 1814-1816 culminating into Sugauli Treaty, under whose terms Nepal lost the territories it had conquered earlier. Even before the Sugauli treaty was concluded, agreement on recruitment of Gurkha soldiers in British East India Company's forces was made, and the first Gurkha Corps was prepared on April 24, 1815(James \&Sheil-Small, 1965, p. 17). It prepared the way for the pro-British foreign policy, ceasing Prithivi Narayan Shah's counseling on maintaining balanced relations with both the neighbors. Jung Bahadur Rana 's rise as a de facto ruler in 1846, his visit to England in 1850, and assistance to British during Sepoy Mutiny of 1857 offered place for British involvement in Nepal's political affairs. Both Ranas and British were comfortable with the arrangements that Jung Bahadur had arranged with British, and as the result of such modus vivendi, Nepal inked a formal treaty with Britain on December 21, 1923 that acknowledged Nepal as a sovereign country. This treaty, in particular, helped Nepal to escape the fate of 536 princely states absorbed under independent India in the line of 'national security exercise' by Saradar Vallabhai Patel of India (Dixit, 1998, p. 26).

Today, rise of China, and the strategic partnership between the US and India to contain China, has once again augmented Nepal's difficulties in managing the interests of major powers, particularly the conflicting interests of India and China in Nepal. In such a context, how Nepal should pursue with the act of balancing while the policy of neutrality and non-alignment have already received sharp criticisms. The relation between India and China is often labelled as one of the most 'electrifying' of this century (Martin, 2015). But there are certain similarities and unusual differences in the foreign policy behaviors of India and China, particularly in dealing with the small countries, like Nepal, whose position in international system is conditioned by three different approaches: globalist, Indo-centric and isolationist approaches 
(Khatri, 1998, p. 12). Until the end of 1950, Nepal pursued an isolationist foreign policy confining its interactions and engagements only with Britain. Although Nepal joined the comity of nations, having acquired the membership of various international and regional organizations since 1955, the revenge of geography compelled Nepal to pursue an Indo-centric approach. Even all the roads to globalism, for Nepal, started from India, until 2016, when Nepal started to diversify its trade and transit routes via China in order to maximize the benefits from the global value chain.

Historically, Nepal has been balancing relations with its two immediate neighbors (Kissinger, 2014, p. 197). But, having adopted the Westphalia model, the two distinct civilizational entities have been reduced to geopolitical rivals, today. The communist system in China is depicted as a perpetual threat to India - the world's largest democracy - and thus a rivalry is constituted. Sino-Indian rivalry has been a constant threat to the neighboring countries like Nepal, who have been aspiring to draw economic benefits from the spectacular economic development in its vicinity (KC \& Bhattarai, 2018, pp.75-96). Their geopolitical contestation in the Himalayan belt and South Asian region has been a major source of insecurity for Nepal. While China's rise already mounted challenges for Nepal, New Delhi has also missed several opportunities to take Kathmandu into confidence. Eminent Persons' Group (EPG) was an appropriate opportunity for India. Officially constituted in 2016 with expert members from both the countries, EPG was mandated to review the entire gamut of bilateral relations and to come up with the key recommendations on the contentious issues. A report was finalized, including the joint recommendations from the experts of both the countries, during the $9^{\text {th }}$ meeting of EPG in Kathmandu in 2018. But Indian Prime Minister has not received the report yet, which has engendered a suspicion that Modi administration has certain reservations with the contents of the report. After over three years, questions are being raised over the relevancy of the report. Nepal's foreign policy of balancing in dealing with its immediate neighbors is reckoned by the foreign policy experts as Nepal's survival strategy, which has its root in $18^{\text {th }}$ century colonial narrative that was further watered during the cold war period. This strategy, in particular, emphasizes on Nepal's geostrategic location and strategic choices that Kathmandu could maneuver.

When Nepal came up with an integrated foreign policy-2020, the significance of 'balancing' is also highlighted to deal with the both, great power competition and great power cooperation. As the geographical variable remains constant, Kathmandu finds the act of balancing as the best policy in coping with the changing dynamics in the regional and international arrangements.

With the rise of China, the geography of Nepal has become strategically important for the United States. In the same manner, India has always perceived Nepal's Himalayan as its defense frontier. When China and the United States perceive each other as threat, Nepal being located next to China, finds the act of balancing more appropriate in evading the probable geopolitical difficulties emanating from great power rivalry. During the First Committee of the 75th session of the UN General Assembly, China's deputy permanent representative to the United Nations Geng Shuang identified the United States as the threat to the international security structure, 
while the United States has also listed China as a threat in its National Security Strategy Report of 2017 for challenging American power and influence 2018 National Defense Strategy of US summarized China and Russia as "revisionist powers" and a threat to the interest of the United States, as they aim to influence world politics with their authoritarian models. Today, the strategic competition between China and the United States is not confined to Southeast Asia. The signing of the Communications, Compatibility and Security Agreement (COMCASA) and Basic Exchange and Cooperation Agreement (BECA) during the $2+2$ meeting between the United States and India's high level Foreign and Defense officials in 2018 and 2020 in New Delhi with an objective to contain China in a new Cold War situation, indicates at the same. Owing to the political, economic, strategic and military overtures, it is ideal for Nepal to remain cushioned in the act of balancing that has always shielded Nepal's sovereignty, political independence and territorial integrity. Most importantly, at the neighborhood, balancing not only lessens the geopolitical vulnerabilities but also maximizes the diversification of Nepal's economic endeavors, as both the neighbors are rising economies. As directed by Divya Upadesh, balancing reinforces not only the conventional survival strategy but also strengthens the strategy of sustenance through the transit diplomacy between the two countries. With the help of balancing, Kathmandu could sustain a balanced relations with the regional powers and major powers. It is relevant to develop amity with all and enmity with none.

Thus, historical knowledge on Nepal's balancing would be a good help to foreign and security policy makers as it provides insights into the contexts and the strategies devised in different periods of time. With such a historical perspective, a realization is developed in the mind of policy makers that Nepal had witnessed such problems in the past and by knowing the past, the challenge of the present becomes more trackable through greater analytical insights, as of balancing.

Meticulous Diplomacy: As the changing global power relations has invigorated the resurrection of geopolitics in the $21^{\text {st }}$ century through the advent of alliance system and defense partnerships, small countries like Nepal must prepare themselves diplomatically. Even if the policy of nonalignment and neutrality is not yielding achievement, Nepal cannot afford to join any alliances. Thus, Nepal should direct its foreign policy through meticulous diplomacy to promote and protect its national interest, sovereignty and territorial integrity. Even the act of balancing may cause tension if not meticulously conducted. Thus, balancing through economic interaction is the best way. Similar realization was present in Divya Upadesh demanding the promotion of national unity, effective institutionalization of foreign affairs, promotion of skillful and tactful diplomacy and effective economic diplomacy.

Before the formation of modern and unified Nepal, Nepal's foreign affairs was not organized or institutionalized. It was only after the unification in 1769, Shah took the initiatives to establish Nepal's foreign office and named it as Jaisi Kotha. He also assigned Kalu Pandey's family to maintain foreign relations with Tibet and Shiva Ram Basnyat's family to look after the relations with South, which shows his meticulousness about the probable geostrategic vulnerabilities. In the diplomatic history of Nepal, the diplomatic 
capability of PN Shah manifested during the unification campaign is astonishing and remarkable. He emphasized on five main elements regarding the national security strategies. Firstly, the unification process, to prevent the expanding British colonial power in the Indian subcontinent. Secondly, the military buildup, for which he designated proficient commanders having an ability to make proper assessment of the situation and take the appropriate steps at the appropriate time. Thirdly, a meticulous diplomacy with British-India and China. Fourthly, he reiterated a balance between offensive and defensive approaches. Fifthly, he highlighted the importance of national security and foreign policy through various policy instruments.

Today while a new world order hasn't fully emerged and the existing world order is also not entirely dismantled, the global politics in transition that is driven by a new regional security environment and budding polarization, resulting into great power rivalry, because of which global governance institutions, multilateralism and regionalism are fissured and weakened (KC \& Bhattarai, 2021, pp. 157-174). In the context of the impact of great power rivalry on South Asian region, Nepal's hopes and aspirations to draw economic benefits from the rise of India and China have also been severely impacted. Still, the prospects of Nepal's economic diplomacy cannot be ruled out. In Divya Upadesh, PN Shah stated: "Export our products and other Herbs to the foreign countries and earn cash out of such commodities. Always try to earn money from external trade. The Country will remain stronger if our people become wealthy. In fact, wealthy people are the treasury (asset) of the State". He was also aware of the benefits of agriculture and industrialization for the economic security and foreign trade. In Divya Upadesh, he stated: "Operate mines even shifting the people from the mining areas. If the land is fit for paddy field, shift houses in any other place and develop system for irrigation, develop a paddy field over there and develop a cultivating land".

Nepal's geography has been variously strategized by its policymakers. Today, to cope with the great power rivalry, Nepal's geography should be manifested in an economic manner. It is often said that Nepal's prosperity depends on its geography. Development economists consider the landlocked status of Nepal a major impediment to its development. Nepal's lack of access to sea has always been held responsible for its underdevelopment. Nonetheless, the signing of the Transit and Transportation Agreement with China in 2016 altered the conventional identity of Nepal as a landlocked or "India-locked" country. Now, with the signing of the treaty, Nepal is land-linked both of its neighbors. Due to this Nepal is expected to reap the benefits of being a bridge between its two giant neighbors. Economists, development planners, foreign policy experts and the business community often accentuate the point that Nepal should strive to establish itself as a trade corridor or a transit country between its two giant neighbors, for its prosperity and development. It is possible by exercising meticulous diplomacy with tactful balancing as it reduces geopolitical vulnerabilities and augments economic opportunities. But the bridge discourse is still an idea in the making; it has not been institutionalized. In the 1970s, late King Birendra had put forward the idea of developing Nepal as a gateway between South and Central Asia. Later, in 2005, while addressing the Afro-Asian Summit in Jakarta, 
former King of Nepal Gyanendra Shah spoke about Nepal's readiness to be an economic transit point between the two Asian economic giants - India and China. Along the same line, former prime minister Minister Pushpa Kamal Dahal made the trilateral proposal during his visit to India in 2010. He again proposed the same during his April 2013 visits to both Beijing and New Delhi. In 2012, former Prime Minister Baburam Bhattarai also envisioned Nepal as an 'economic bridge' between China and India. Unlike his predecessors whose emphases on the spirit of trilateral partnership were limited to statements and speeches, former prime minister KP Sharma Oli moved a step ahead by signing transit and transportation treaty with China in 2016 . He had signed the treaty in the wake of the 2015 Indian blockade on Nepal. With its signing, Nepal is now in a favorable position to act as a "bridge" between China and India, at least geographically. Along the same lines, former Prime Minister Pushpa Kamal Dahal again floated the "bridge" idea during his Goa visit, where he simultaneously met the Chinese President as well as the Indian Prime Minister at the sidelines of the BRICS-BIMSTEC Outreach Summit in October 2016. The $1,415-\mathrm{km}$ Nepal-Tibet border is definitely advantageous and out of 312 passages linking Tibet with South Asia, Himalayan belt in Nepal provides 184 such routes. On the South, Nepal borders Uttar Pradesh (UP), Bihar, West Bengal, Uttarakhand and Sikkim. Thus, geographically, Nepal is in a favorable position to bridge the two economies. But, India's reservation on Nepal's proposal of trilateralism citing security reasons has once again raised the geopolitical concerns (Behera, \& Mayilvaganan, 2021). Here, it needs to be understood that Divya Upadesh doesn't provide clear and direct answers to the present-day policy problems. For instance, if we turn the pages of Divya Upadesh to find readymade answers for the ways to deal with India's reluctance over Nepal's proposal of trilateralism, it won't make any sense. The pages should be turned with an attitude to obtain historical knowledge about the ways to minimize the geopolitical risks. In doing so, history may unlock Indian motives and how characteristics of Indian foreign policy is essentially driven by geographical determinism. Afterall, Divya Upadesh lets us understand that among different factors shaping the foreign policy of a country, geopolitical realities occupy a prominent position. While resisting geopolitical realities, Kathmandu must pay heed to skillful balancing so that misperception and distrust with the neighboring countries could be avoided. Thus, Nepal's act of balancing needs to go beyond the short-term requirements and tread on a pragmatic foreign policy of balancing imbedded in ground realities, instead of confining foreign policy objectives to discourses.

\section{Conclusion}

While the nature and scope of foreign and national security policies is characteristically crisis-driven, this qualitative study has discovered the significance of looking back into history to rediscover the national security strategies and policies that doesn't fulfill the entire contemporary needs but offer strategic perspective through analogies and historical knowledge. As this study has realized that the conventional survival strategies Nepal adopted for decades have failed to address the challenges faced while managing the interest of major powers, it is apt to turn the pages of Divya Upadesh, and rediscover the act of effective balancing in minimizing the geopolitical threats emanating from the great power competition. Today, with the 
increasing strategic competition between the United States and China, the concept of a new cold war is being brewed with the U.S., its European and Pacific allies, along with India standing on one side, while China, Russia, Central and Southeast Asia and Pakistan, on the opposite side. In such a context of the resurgence of great power rivalry, how far Nepal's conventional survival strategies would be of advantage in managing their interests and concerns in the Himalayan region. Hence, it is more relevant to take refuge in Divya Upadesh, the foundation stone of Nepal's national security to help policy makers understand the success and failure of balancing act. Nepal has conventionally attempted to manage the interests of major powers by balancing as Kathmandu can't afford entering into any kinds of power blocs or strategic alliance owing to its geostrategic location. But mere balancing won't yield positive results, until it is wired with meticulous diplomacy, particularly to fulfill Nepal's search for prosperity through transit diplomacy. Situated between the two Asian economic giants, and branded by Beijing as the gateway to enter South Asia, Nepal, as highlighted in its programs, plans and policies intends to achieve a growth-oriented development and infrastructure-driven prosperity by upgrading herself as a transit between India and China with the help of BRI projects. In doing so, foreign and security policy makers shouldn't forget to develop a deeper interaction with historians by terminating mutual perplexities to improve history-policy relationship.

\section{References:}

Acharya, J. (2014). Nepal's Foreign Policy: A Reflection. Kathmandu: Sopan Monthly.

Acharya, M.R. (2020). Nepal's National Interests, Foreign Policy and Strategic Affairs.
Kathmandu: Policy Research Institute

Adhikari, D. (2020). Nepal ruling party split over US aid threat to China relations. Nikkei Asia. https://asia.nikkei.com/Politics/Internationalrelations/Nepal-ruling-party-split-over-USaid-threat-to-China-relations

BBC. (2021). G7 summit: Spending plan to rival China adopted. $B B C$.

BBC. (2020). US-India 2+2: Crucial defence deal signed. $B B C$. https://www.bbc.com/ news/world-asia-india-54655947, accessed 12 November 2020

Behera, A.,\& Mayilvaganan, M. (2021). The China-Nepal-India Economic Corridor: wishful thinking or regional aspiration beyond rhetoric? The Commonwealth Journal of International Affairs. Routledge. DOI: 10.1080/00358533.2021.1904586

Bhattarai, R \& Cave, R. (2009). Changing Security Dynamics in Nepal. Kathmandu: Nepal Institute for Policy Studies

Bhattarai, R \& Wagle, G.S. (2010). Emerging Security Challenges of Nepal. Kathmandu: Nepal Institute for Policy Studies

Bhatt, D. (2010). Challenges of Integration and Rehabilitation of the Combatants of Maoist. Army. In Rajan Bhattarai and Rosy Cave (eds) Emerging Security Challenges of Nepal. Kathmandu: Nepal Institute for Policy Studies

Budhathoki, S. (2009). Mainstreaming the Security Sector Reform Agenda in Nepal. In Rajan Bhattarai and Rosy Cave (eds) Changing Security Dynamics in Nepal. Kathmandu: Nepal Institute for Policy Studies

Buzan, B. (1991). New Patterns of Global Security in the Twenty-First Century International Affairs. Oxford University Press pp. 431-451.

Constitution of Nepal. (2015). Provisions Relating to National Security. Nepal Law Commission

DoD.( 2019). Indo Pacific Strategy Report Preparedness, Partnership and Promoting a Networked Region

DoS.(2019). A Free and Open and Indo-Pacific 
Advancing a Shared Vision. US Department of State

Fazal, TM. (2004). State Death in the International System. International Organization. 58(2), pp. 311-344

Gautam, R. (2074 B.S.). Political history of Nepal, Kathmandu: Bhudipuran Prakashan

Ghimire, B.(2020). As India and China fight, Nepal should stand neutral. Republica.

Gupta, S.(2020, June 10). In Nepal's map tactics, a reflection of China's growing footprint in Kathmandu. Hindustan Times.

Handel, M.I. (1995). The Evolution of Israeli Strategy: The Psychology of Insecurity and the Quest for Absolute Security. In W. Murray, M. Knox \& A. Bernstein (Eds.) The Making of Strategy: Rulers, States and War(pp. 53-75). New York, NY: Routledge

Harold, J \& Sheil-Small, D.( 1965). The Gurkhas, London: Macdonald, p. 17

Jha, H.B. (2020). Rivalry between US and China in Nepal delays MCC. Observer Research Foundation.https://www.orfonline.org/expertspeak/rivalry-between-us-and-china-in-nepaldelays-mcc-60298/

J.N. Dixit. (1998). Across Borders: Fifty Years of India's Foreign Policy, New Delhi: Pincus Books, p. 26

KC, K., \& Bhattarai, G. (2021). Nepal Amid SinoIndian Contestation. In Nian Peng, Ghulam Ali \& Yi Zhang (Eds.) Crossing the Himalayas, Buddhist Ties, Regional Integration and Great-Power Rivalry (pp. 157-174 ) Spinger Singapore

Khanal, Y.N. (2000). Nepal's Non-Isolationist Foreign Policy. Satyal Publications.

Khatri, S. (1998). Nepal in the International System. In Anand Aditya (Eds.), The Political Economy of Small States, NEFAS.

Kissinger, H. (2014). World Order. New York: Penguin, p.179.

Lippmann, W. (1943). US Foreign Policy: Shield of the Republic. Boston: Little, Brown and Company

Martin, P. (2015). Beyond 1962, How to Upgrade the Sino-Indian Relationship. Foreign Affairs. http://fnvaworld.org/beyond-1962-how-toupgrade-the-sino-indian-relationship/

MCC. (2017).U.S. and Nepal Sign \$500 Million Compact. United States of America. https:// www.mcc.gov/news-and-events/release/ release-091417-nepal-signing-event

Mihaly, E. B.( 1965). Foreign Aid and Politics in Nepal. Kathmandu: Himal Books

National Planning Commission. (2020). Peace, Order and Security of the The Fifteenth Plan (Fiscal Year 2019/20 - 2023/24). National Planning Commission.

Republica (2020). India continuously ignoring Nepal's call for holding talks to resolve border issues: FM Gyawali. Republica.

Rose, L. (1971). Nepal, Strategy for Survival. University of California, Berkeley

Ross, Thomas E. (1986). "Buffer States: A Geographer's Perspective". In John Chay and Thomas E. Ross( Eds.) Buffer States in World Politics, p. 16

Sapkota, B. (2009). The Nepali Security Sector: An Almanac. Geneva Centre for the Democratic Control of Armed Forces, Geneva, Switzerland and European Studies Center, Faculty of Humanities, University Pecs, Hungary

Shaha, R. (1965). Heroes and Builders of Nepal. Oxford University Press, p.86

Sharma, J.R \& Seddon, D. (2020).Putting the MCC in context. Nepali Times. https://www. nepalitimes.com/latest/using-the-delay-inmcc-to-dissect-it/

Stobdan, P. (2019).The Great Game in the Buddhist Himalayas: India and China's Quest for Strategic Dominance. Vintage, Penguin Random House

Stiller, L. F. (1968). Prithvinarayan Shah in 
the Light of Dibya Upadesh, Kathmandu: Himalaya Book Centre.

The Kathmandu Post. (2019). Chinese investment should serve the interest of Nepal and not just China, US official says.. The Kathmandu Post. https://kathmandupost. com/national/2019/02/26/chinese-investmentshould-serve-the-interest-of-nepal-and-notjust-china-us-official-says

The Rising Nepal. (2019). No Dilemma on MCC Ratification: Gyawali. The Rising Nepal.. https://risingnepaldaily.com/main-news/nodilemma-on-mcc-ratification-gyawali

The Times of India (2020). Border row with India: Nepal's parliament approves new map. The Times of India.

The Wire (2020). Army Chief Says Nepal Objected to India's Link Road to Lipulekh at Someone Else's Behest. The Wire.

United Nations Development Program. (1994). Human Development Report. New York: Oxford University Printing Press, p. 22

Upreti, B., Bhattarai, R., Wagle, G.S. (2013). Human Security in Nepal: Concepts, Issues and Challenges (eds). Kathmandu: Nepal Institute for Policy Studies and South Asia dination Office of NCCR (North-South)

Vater, J.J. (2020).The Great Game in Nepal: A Himalayan State's Search for Higher Ground. ISAS Working Paper. Institute of South Asian Studies

Wagle, A. (2020). What the Biden win means for Nepal. The Kathmandu Post. https:// kathmandupost.com/columns/2020/11/09/ what-the-biden-win-means-to-nepal

Wagle, G.S. (2009). National Security Policy and Role of National Security Council. In Rajan Bhattarai and Rosy Cave (eds) Changing Security Dynamics in Nepal. Kathmandu: Nepal Institute for Policy Studies

Watson, C.A. (2008). U.S. National Security: A Reference Handbook: Santa Barbara, Denver, Oxford: ABC-CLIO, Inc.

Wolfers, A. (1962). Discord and Collaboration: Essays on International Politics. Baltimore: The John Hopkins University Press.

Zheng, S. (2020). China-India border dispute may force South Asian neighbors to pick a side. South China Morning Post. 